\title{
Establishing Civilian Control over the Armed Forces
}

\author{
Broto Wardoyo \\ Departermen Hubungan Internasional \\ Universitas Indonesia
}

\begin{abstract}
Using simple regression, this paper examines the explanans to the degree of civilian control over the armed forces. This paper takes into consideration four of the most considered independent variables to explain the degree of civilian control over the armed forces, i.e. internal threat, economic condition, civil liberties, and military access to resources. It suggests that the degree of internal threat is negatively correlated with the degree of civilian control over the armed forces while economic condition, civil liberties, and defense spending, or access to resources, enhance the degree of civilian control over the armed forces. In addition, it also suggests that civil liberties have the highest influence to the degree of civilian control over the armed forces, controlling the other independent variables. Since civil liberties are closely related to degree of democracy, it basically confirms previous research that suggest the degree of civilian control is closely and positively correlated with the maturity of democracy.
\end{abstract}

Keywords: civilian control over the armed forces, internal threat, economic condition, civil liberties, military access to resources, regression.

Tulisan ini menjelaskan eksplanan-eksplanan dari derajad kontrol sipil atas militer dengan menggunakan regresi sederhana. Tulisan ini mempertimbangkan empat independen variabel yang paling sering dikaji untuk menjelaskan derajad kontrol sipil atas militer, antara lain: ancaman internal, kondisi ekonomi, kebebasan sipil, dan akses militer terhadap sumber-sumber daya. Tulisan ini menemukan bahwa derajad ancaman internal berkorelasi negatif dengan derajad kontrol sipil atas militer, sementara kondisi ekonomi, kebebasan sipil, dan akses militer terhadap sumber-sumber daya berkontribusi positif terhadap derajad kontrol sipil atas militer. Tulisan ini juga meemukan bahwa kebebasan sipil memiliki kontribusi terbesar dalam mempengaruhi derajad kontrol sipil dengan mengontrol tiga variabel yang lain. Mengingat kebebasan sipil memiliki keterkaitan dengan tingkatan demokrasi, tulisan ini mendukung penelitian-penelitian sebelumnya yang menyatakan bahwa derajad kontrol sipil atas militer terkait secara positif dengan kematangan demokrasi.

Kata kunci: kontrol sipil atas militer, ancaman internal, kondisi ekonomi, kebebasan sipil, akses militer terhadap sumber-sumber daya, regresi. 


\section{Introduction}

What factors influence the degree of civilian control over the armed forces the most? Numerous studies have been conducted to examine what explains the degree of civilian control over the armed forces. They were mostly conducted as case study of single country or comparison of few cases within certain region or the so-called wave of democratization process. Examples of the comparative work include Pion-Berlin's work (2001) on Latin America, Edmunds, Cottey, and Forsters' study (2006) on post-Communist Eastern Europe, Alagappa (2001a) and Croissant, et.al. (2013) pieces on Asia, and Mietzner's research (2011) on Southeast Asia. The list, of course, could be extended to exhaustion. While these studies are exceptionally brilliant in employing in-depth studies on the case (or cases), including examining the historical, social and political contexts of each case to make sense of the degree of civilian control over the armed forces, they are lacked of general pattern-which, should be noted, is not the focus of those studies. This paper examines this issue by conducting a statistical analysis with 81 cases across different regions and political systems to seek the general explanation of the puzzle. Such an attempt has been rarely conducted due to various reasons, including but not limited to the difficulty in clarifying the concept. Statistical analysis permits us to draw causal inferences between two variables with higher precision (Braumoeller and Sartori in Sprinz and WolinskyNahmias, 2004). Hence, conducting a statistical analysis on this topic would strengthen previous works with case and comparison studies. In addition to statistical analysis, scholars have also developed multimethod research to overcome the limitation of case and comparison studies such as using Qualitative Comparative Analysis (QCA) (Goertz 2016). Kuehn, et.al. (2016) employ a QCA method in explaining the degree of civilian control over the armed forces. This study follows Kuehn, et.al.'s (2016) attempt by extending the dataset and using statistical analysis in explaining the degree of civilian control over the armed forces.

Why bother studying degree of civilian control over the armed forces? Scholars have long argued that the role of the armed forces is very crucial in transition to democracy. For example, Lee (2015) argues that military's defection is crucial in determining the success of people power in bringing down authoritarian rule. Military's importance is not only taking place during the early phase of transition but also in the period that follow. Huntington (1957) develops the concept of professional military as prerequisite for democratic society in which he puts an emphasis on the need to establish a good degree of objective civilian control over the armed forces. Hence, examining variables that explain the degree of civilian control over the armed forces is also worth conducting. 
This study takes into consideration four of the most "considered" variables-most commonly referred as independent variables that influence the degree of civilian control over the armed forces-to explain the degree of civilian control over the armed forces, i.e. internal threat, economic condition, civil liberties, and military access to resources. Hence, whether or not those variables have the capacity to explain the degree of civilian control over the armed forces is worth researching.

This paper is organized into the following. The next part clarifies the dependent variable. It then examines the theoretical debate concerning the independent variables that explain the degree of civilian control over the armed forces, such as: internal threat, economic condition, civil liberties, and military access to resources. This paper runs a simple regression model to explain the question posted in the beginning of this paper. A short conclusion and limitation of this study are given towards the end of this paper.

\section{The Dependent Variable}

Measuring the degree of civilian control over the armed forces is not an easy task. To begin with, a definition of civilian control is needed. Desch (1999) and Kemp and Hudlin (1992) define the degree of civilian control over the armed forces by looking at whether it is the armed forces or civilian's preferences prevail when theirs are diverged. Civilian control over the armed forces is considered weak when military preferences prevail most of the time and on the contrary, is considered as strong when civilian preferences prevail most of the time. However, this definition is not without problems. To begin with, both civilian and military preferences are not necessarily clear and what is stated is not necessarily their real preferences. Nor, it is easy to clearly see their preferences and the clash of their preferences. Hence, to avoid those problems, most studies on civilian control over the armed forces rely on the institutional element of civilian control over the armed forces, such as the existence of set of regulations to endure military compliance.

The institutional approach in measuring the degree of civilian control over the armed forces relies on the clarity to differentiate the so-called military from non-military areas. It also, as a consequence, requires the distinction between military and non-military areas. Stepan (1988) argues that non-military refers to three different entities: the state, political society, and civil society. Alagappa (2001) refers the term civilian to political, administrative, and juridical institutions in defining civilian. In this paper the term civilian refers to civilian administrative authority (executive) and neglecting legislative and society's control over the armed forces. Hence, this paper does not differentiate the subjective from objective control or whether the control is one of democratic 
control or not-which is the most common way to categorize civilian control over the armed forces. Huntington (1957) divides civilian control into objective control (which basically considered the armed forces as under state control) and subjective control (in which the armed forces are under certain group or personal control of autocrat leader). In addition, scholars also propose the term democratic civilian control over the armed forces which basically include oversight by executive, legislative, as well as public (civil society) to create a good security governance (Bruenau and Matei, eds. 2013).

Clear distinction between military and non-military affairs is a key to measure military compliance to civilian orders since it would likely to prevent military penetration to civilian areas (Welch, Jr. and Smith 1974, p.39-42). Scholars usually divide five areas in which military involvement would define the degree of control, which include: leadership selection, public policy, internal security, external defense, and military organization (Trinkunas 2005, pp.6-8; Croissant, Chambers, and Völkel in Croissant and Bunte, eds., 2011, pp.193; Croissant 2011, p.4-5; Croissant, et.al, 2013, p.29-32; Kuehn, et.al., 2016, pp.5). The armed forces should be involved only on the technical aspect of the last two areas. Croissant, et.al. (2013) and Kuehn, et.al. (2016) then split each of these areas into two dimensions: policy-making and policy-implementation.

This paper follows the above mentioned distinction in measuring civilian control over the armed forces. This paper includes the dataset of 28 third wave democracies from Kuehn, et.al. and extends this dataset with Croissant's dataset (2011) on East Asia and Croissant and Kuehn's dataset (in Gandhi and Ruiz-Rufino, eds., 2015) on Third World countries that share similar measurement technique. In addition, this paper also considers Geddes, Wright, and Franz's dataset (2014) on regime types to expand the dataset. They develop the dataset on military regimes and classified those regimes into autocratic regimes (monarchy, personal, party, military, or combination of them) and democratic regimes. This paper includes the military regimes as part of the worst civilian control over the armed forces, while their dataset on established democracies are considered as having the best civilian control over the armed forces. All cases (countries) are measured in 2010.

\section{The Independent Variables}

Competing explanations on what factors influence the degree of civilian control over the armed forces have long existed yet there is a lack of conclusion among these explanations. They range from structural factors such as threat environment, economic condition or performance, civilian power and unity, to the so-called agencies-related factors such as 
military ideology, military unity and organizational coherence, and military economic interest (Croissant, 2004; Kuehn and Lorenz, 2011 in Feaver 1996). This paper focuses on internal threat (Global Peace Index/GPI), economic condition or GDP (The World Bank), civil liberties (Freedom House Index), and defense spending (SIPRI).

Theoretical framework on threat environment and the degree of civilian control has been far from conclusion when we consider the external threat environment. Laswell (1941) argues that, under a challenging international situation, the degree of civilian control would be lower since the armed forces would be tempted to take over power to ensure the effectiveness of governing to cope with the threat. On the other hand, Desch (1999) argues the otherwise, noting that a higher external threat would lead the armed forces to focus on their task of defending the country and hence create a better civilian control over the armed forces. The relations between internal threat environment and civilian control, on the other hand, are more coherent. They tend to conclude that the degree of civilian control of the armed forces would be higher when the degree of internal threat is lower. Therefore, this paper focuses on the internal rather the external threat environment and develops the first hypothesis as the following:

\section{H1. The higher the degree of internal threat, the lower the degree of civilian control over the armed forces.}

To measure internal threat environment, this paper uses GPI provided by Institute for Economics and Peace (visionofhumanity.org). This index ranks countries according to their degree of peacefulness by looking at three different aspects: (1) the level of safety and security in society, (2) the extent of domestic and international conflict, and (3) the degree of militarization. However, this paper makes slight changes on the GPI index by excluding some indicators of the first aspect, the international conflict measurement of the second aspect and the third aspect of the GPI index measurement. Hence, in details, it considers the following aspects to be measured as indicators of internal threat environment: perception of crime, number of police force, intensity of internal conflict, access to weapons, violent demonstrations, violent crime, political instability, political terror, terrorism impact, the death from internal conflict, and internal conflict fought. Those are indicators that are highly related to the likelihood of military deployment to assist the internal security apparatus. The GPI uses an index with maximum score of 5 (refers to the highest level of internal threat) in which in this paper is changed to 1 (equal to 5 in the original index, and hence o for 1 in the original index).

The second independent variable that explains the degree of civilian control is economic condition. It is widely believed that better economic performance would lead to higher civilian control over the armed forces. 
Working on the post-Franco Spain, Agüero (1995) contends the importance of economic condition in the establishment of civilian supremacy. Hence, this study defines the second hypothesis as the following:

H2. The higher the degree of economic condition, the higher the degree of civilian control over the armed forces.

To measure economic condition, this paper uses GDP dataset provided by The World Bank (worldbank.org), with the exception of North Korea, Myanmar, Syria, and Taiwan. The GPD data for those countries are taken from Trading Economics (tradingeconomics.com 2016). This paper simplifies the real number of GPD into proportion of the highest number of GDP (hence the highest number of GDP is equal to 1 and the rest is adjusted accordingly).

The third independent variable to be assessed is civil liberties. The term civil liberties refer to civilian freedom to engage in political activities without coercive constraints. It basically indicates the degree of civilian to express themselves in various sectors. Alagappa (2001a) considers coercion as important determinant for military influence or rule. Civil liberties can be considered as indicator of civilian power. Welch, Jr. and Smith (1972) and Aguero (1995) suggest that the strength of civilian power would significantly influence civilian control over the armed forces. Hence,higher civil liberties would imply a stronger society and, as a consequence, lead to a stronger civilian control over the armed forces. The third hypothesis of this study, therefore, is:

H3. The higher the degree of civilian liberties, the higher the degree of civilian control over the armed forces.

Freedom House provides a yearly civil liberties index that includes freedom of expression and belief, freedom of associational and organizational, independency of the rule of law, and protection of personal autonomy and individual rights (freedomhouse.org 2016). Freedom House also provides political freedom index, but since this particular index also includes freedom to elect national leadership and freedom from military intervention, which is included in the measurement of civilian control over the armed forces, it will not be used to measure civilian political power. This index measures the degree of civilian liberties from 1 to 7 with 1 equal to the highest. In this paper, the score is adjusted with 1 equal to 1 in the original index (the highest freedom) and 0 equal to 7 in the original index (the lowest freedom).

The fourth independent variable is military access to resources. Abrahamsson (1972) has long argued that protecting their corporate interests are one of the fundamental reasons for military domination in 
politics. Nordlinger (1977) identifies adequate budgetary support as one of the most important corporate interests of the armed forces. However, there is no clear indication of to what extent the sum of military spending would satisfy the armed forces. In addition, there is also a strong belief that resources spent for the armed forces is basically a waste of resource since it will not bring any benefits for domestic programs. Hence, it leads to the debate of "gun-versus-butter" that traditionally revolves around whether the government should prioritize defense budget over welfare budget or the other way around (Hess 2009). Looking at these arguments, it is safe to assume that the higher the allocation of budget share for the armed forces, the lower their involvement in politics will be. Thus, the degree of civilian control over the armed forces will be higher. The fourth hypothesis, therefore, can be proposed as the following:

H4. The wider the access to resources, the higher the degree of civilian control over the armed forces.

There are two ways to measure military access to resources: i.e. by looking at the total defense budget allocated for the armed forces establishment or by looking at the share of this budget as percentage of GDP. Both choices suffered from similar inadequacies. Measuring the total defense spending usually does not include another share of budget allocated to personnel's welfare. In addition, defense budget usually includes the civilian post of defense establishment, such as budget allocation from the Ministry of Defense. Therefore, it is clear that the defense budget does not reflect the actual defense spending as well. As a result, the share of budget from total government spending does not reflect the real share of spending as well. This paper uses the former way of measuring military access to resources since it indicates the total sum of budget allocated to the armed forces which is less problematic in term of "gun versus butter debate" (considering the share of GDP would also mean making percentage of defense spending in zero-sum game situation against the non-defense spending, meaning when the share of defense budget is high, the share of non-defense budget is low). This paper uses the dataset provided by SIPRI (with the exception of North Korea and Myanmar) (sipri.org 2015). Similar to the measurement of GDP, the defense budget data is also adjusted with the highest number of defense budget equals to 1 and the rest is measured as proportion of the highest.

\section{Analysis}

The descriptive statistic of the dataset reveals that the mean score for the degree of civilian control over the armed forces of those 81 countries is 0.76. It means that most countries studied in this paper have a relatively 
good degree of civilian control over the armed forces. Distribution by continent suggests that $39.5 \%$ of the cases is from Europe, $30 \%$ is from Asia, 19\% is from America, and the rest is from Africa. This distribution sufficiently explains the relatively high mean score of the degree of civilian control over the armed forces. The lack of data collection in Asia, America and Africa is the one of the reason for the relatively imbalance distribution of cases across continents. The mean score of the degree of civilian control over the armed forces in Europe is also the highest in comparison to the other three continents. The total of 32 countries examined in this paper represents more than half member of this continent. The representation of Africa in this study is somehow very low, since it covers only 8 out of 50 African countries.

Instead, this paper runs regression analysis to explain the degree of civilian control over the armed forces by considering the four independent variables (internal threat, economic condition, civil liberties, and access to resources/defense spending). Table 1 shows the result of the regression analysis using Stata version 12 with $\mathrm{p}<0.05$.

Table 1. Result of regression analysis*

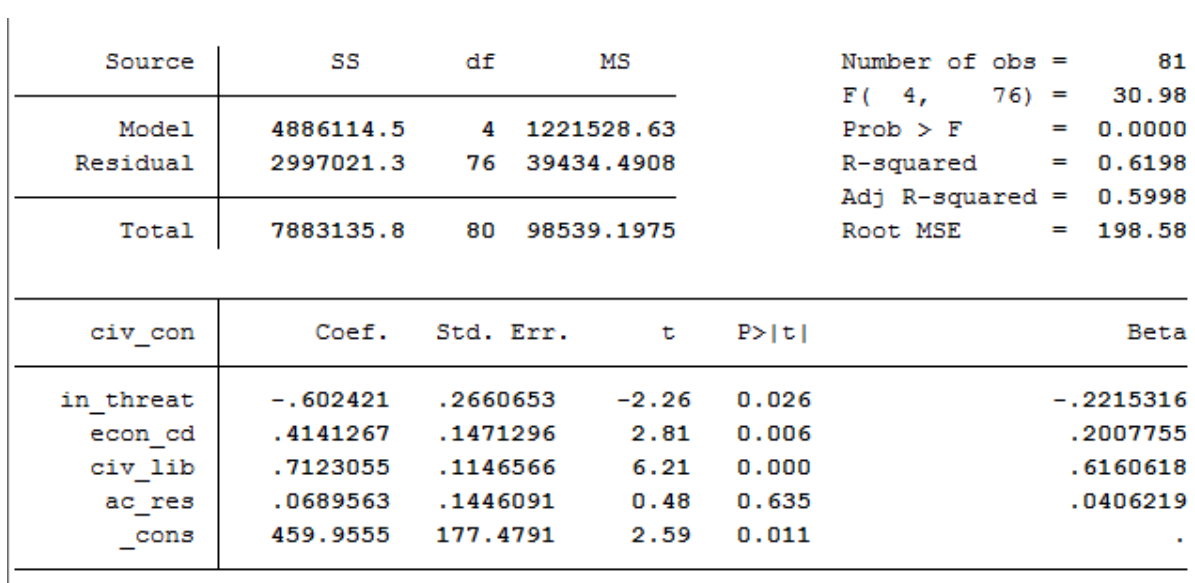

*with $\mathrm{p}<0.05$

The result suggests that those four variables can $59.9 \%$ explain the dependent variable. The all four hypotheses are proven, in which the degree of internal threat is negatively correlated with the degree of civilian control over the armed forces while economic condition, civil liberties, and defense spending, or access to resources, enhance the degree of civilian control over the armed forces. Among those four variables, civil liberties have the highest influence to the degree of civilian control over the armed forces, controlling the other independent variables. It basically suggests that civilian control over the armed forces 
would be relatively higher when civilian groups are free from coercion. Since civil liberties is closely related to degree of democratization, it basically confirms previous research that suggest the degree of civilian control is closely and positively correlated with the maturity of democracy.

Internal threat plays a relatively lower influence, in comparison with civil liberties and controlling other independent variables. It confirms the findings of Staniland (2008) and McMahon and Slantchev (2015) that the explanatory power of internal conflict is somehow limited. Hence, they suggest to consider internal threat as independent variable that influences other intervening variable to explain the degree of civilian control over the armed forces, with Staniland proposes military organizational structure and McMahon and Slantchev propose the perception of threat as intervening variables. Economic condition also positively influences the degree of civilian control over the armed forces with less explanatory power in comparison to the two already-explained variables, controlling other independent variables. However, what is surprising is the result for access to resources, which has a lack of significance in explaining the degree of civilian control over the armed forces.

\section{Conclusion}

This paper has shown the influence of four explanans (degree of internal threat, economic condition, the degree of civil liberties, and access to resources) of the explanandum civilian control over the armed forces. There are, however, limitations with the findings of this paper. First, this paper treats the degree of civilian control over the armed forces as static variable. By being "static", it means that the degree of civilian control over the armed forces is measured in one year only. A time-series examination of degree of civilian control over the armed forces would have a more reliable outcome since it captures the dynamic in civilmilitary relations.

Second, this paper focuses on institutional arrangements (by looking at military role policy-making and policy-implementation) without taking into consideration behavioral factors. Studies on civil-military relations have suggested that most research on this subject suffer from the socalled "first-generation fallacy," which means that they do not really capture the essence of military submission (Cottey, Edmunds, and Forsters 2001; Mietzner 2006).

Finally, in particular, this paper does not cover the cultural-based approach in its independent variable to explain the degree of civilian control over the armed forces. Instead, this research only considers 
military interest to represent the agency-related factors that have been criticized by scholars for being unclear and vague. Lee (2008), for example, suggests that the concept of military interest suffers from several fallacies since it basically assumes that all militaries have similar interests and it assumes that military interest is both rational and material. Instead, scholars usually point out on military culture to explain the degree of civilian control (Huntington, 1957; Finer, 1962; Alagappa, 2001b; Lee, 2008).

\section{References}

\section{Books}

Abrahamsson, Bengt, 1972. Military, Political Power, and Professionalism. Beverly Hills, California: SAGE.

Alagappa, Muthiah (ed.), 2001a. Coercion and Governance: The Declining Political Role of the Military in Asia.Stanford: Stanford University Press.

Alagappa, Muthiah (ed.), 2001b. Military Professionalism in Asia: Conceptual and Empirical Perspectives. Hawaii: East-West Center.

Bruneau, Thomas C., and Florina Cristiana Matei (eds.), 2013. Routledge Handbook on Civil-Military Relations. Oxon and New York: Routledge.

Croissant, Aurel, 2011. Civilian Control over the Military in East Asia. Seoul: The Asia Institute.

Croissant, Aurel, Paul W. Chambers, and Phillip Völkel, "Democracy, the Military and Security Sector Governance in Indonesia, the Philippines and Indonesia”, in Aurel Croissant and Marco Bünte (eds.), 2011. The Crisis of Democratic Governance in Southeast Asia. Hampshire and New York: Palgrave MacMillan, pp.190208.

Croissant, Aurel, et.al., 2013. Democratization and Civilian Control in Asia. Hampshire and New York: Palgrave.

Croissant, Aurel and David Kuehn, "The Military Role in Politics," in Jennifer Gandhi and Rubén Ruiz-Rufino (eds.), 2015. The Routledge Handbook of Comparative Political Institutions. London: Routledge, pp.258-277.

Danopoulos, Constantine P. (ed.), 1992. Civilian rule in the Developing World: Democracy on the March. Boulder and Oxford: Westview Press.

Desch, Michael C., 1999. Civilian Control of the Military: The Changing Security Environment. Baltimore: John Hopkins University Press. 
Edmunds, Timothy, Andrew Cottey, and Anthony Forsters (eds.), 2006. Civil-Military Relations in Postcommunist Europe: Reviewing the Transition. Oxon and New York: Routledge.

Finer, Samuel E., 1962. The Man on Horseback: The Role of the Military in Politics. London: Pall Mall.

Hess, Gregory D. (ed.), 2009. Guns and Butter: The Economic Causes and Consequences of Conflict. Cambridge, Massachusetts and London: The MIT Press.

Huntington, Samuel P., 1957. The Soldier and the State: The Theory and Politics of Civil-Military Relations. Cambridge: Belknap.

Mietzner, Marcus, 2006. The Politics of Military Reform in PostSuharto Indonesia: Elite Conflict, Nationalism and Institutional Resistance. Hawaii: East-West Center.

Mietzner, Marcus (ed.), 2011. The Political Resurgence of the Military in Southeast Asia: Conflict and Leadership. Oxon and New York: Routledge.

Nordlinger, Eric A., 1977. Soldiers in Politics: Military Coups and Governments. Englewood Cliffs: Prentice Hall.

Pion-Berlin, David (ed.), 2001. Civil-Military Relations in Latin America: New Analytical Perspectives. Chapel Hill: University of North Carolina Press.

Sprinz, Detlef F. and Yael Wolinsky-Nahmias, 2004. Models, Numbers and Cases: Methods for Studying International Relations. Ann Arbor: The University of Michigan Press.

Stepan, Alfred, 1988. Rethinking Military Politics: Brazil and the Southern Cone. Princeton, New Jersey: Princeton University Press.

Trinkunas, Harold A., 2005. Crafting Civilian Control of the Military in Venezuela: A Comparative Perspective. Chapel Hill: University of California Press.

Welch, Jr., Claude E. and Arthur K. Smith, 1974. Military Role and Rule: Perspectives on Civil-Military Relations. Belmont, California: Duxbury Press.

\section{Journals}

Cottey, Andrew, Timothy Edmunds, and Andrew Forster, 2002. "The Second Generation Problematique: Rethinking Democracy and Civil-Military Relations", Armed Forces and Society, 29(1): 3156.

Croissant, Aurel, 2004. "Riding the Tiger: Civilian Control and the Military in Democratizing Korea",Armed Forces and Society, 30(3): 357-381.

Feaver, Peter D., 1996. "Civil-Military Problematique: Huntington, Janowitz, and the Question of Civilian Control",Armed Forces and Society, 23(3): 149-178. 
Geddes, Barbara, Joseph Wright, and Erica Frantz, 2014. "Autocratic Breakdown and Regime Transitions",Perspectives on Politics, 12(2): 313-311.

Goertz, Gary, 2016. "Multimethod Research", Security Studies, 25: 3-24.

Kemp, Kenneth W. And Charles Hudlin, 1992. "Civil Supremacy over the Military: Its Nature and Limits",Armed Forces and Society, 19(1): 7-26.

Kuehn, David and Phillip Lorenz, 2011. "Explaining Civil-Military Relations in New Democracies: Structure, Agency, and Theory Development",Asian Journal of Political Science, 13(5): 231-249.

Kuehn, David, et.al., 2016. "Conditions of Civilian Control in New Democracies: An Empirical Analysis of 28 'Third Wave' Democracies", European Political Science Review. Available on CJO 2016 doi:10.1017/S1755773916000011.

Laswell, Harold, 1941. "The Garrison State",American Journal of Sociology, 46(4): 455-468.

Lee, Terence, 2008. "The Military Corporate Interests: The Main Reason for Intervention in Indonesia and the Philippines?",Armed Forces and Society, 9(3): 491-502.

McMahon, R. Blake and Branislav L. Slantchev, 2015. "The Guardianship Dilemma: Regime Security through and from the Armed Forces",The American Political Science Review, 109(2): 297-313.

Staniland, Paul, 2008. "Explaining Civil-Military Relations in Complex Political Environments: India and Pakistan in Comparative Perspective",Security Studies, 17(2): 322-362.

\section{Online Articles}

The World Bank. 2016. "GDP (Currency US\$)" [online] http://data.worldbank.org/indicator/NY.GDP.MKTP.CD

Freedom House. 2016. "Anxious Dictators, Wavering Democracies: Global Freedom under Pressure" [online] https://freedomhouse.org/report/freedom-world/freedomworld-2016

SIPRI. 2015. "SIPRI Military Expenditure Database" [online] https://www.sipri.org/databases/milex

Trading Economics. 2016. "Trading Economic Home Page" [online] http://www.tradingeconomics.com/

Vision of Humanity. 2016. "Global Peace Index" [online] http://www.visionofhumanity.org/\#/page/indexes/globalpeace-index. 


\section{Appendix 1. Dataset}

\begin{tabular}{|c|c|c|c|c|c|c|}
\hline No & case & $\overline{\text { civ_con }}$ & in_threat & econ_cd & civ_lib & $\overline{\text { ac_res }}$ \\
\hline $\mathbf{1}$ & Albania & 1.000 & 0.425 & 0.002 & 0.667 & 0.212 \\
\hline 2 & Algeria & 0.000 & 0.593 & 0.030 & 0.333 & 0.380 \\
\hline 3 & Argentina & 1.000 & 0.417 & 0.031 & 0.833 & 0.101 \\
\hline 4 & Australia & 1.000 & 0.312 & 0.058 & 1.000 & 0.201 \\
\hline 5 & Austria & 1.000 & 0.292 & 0.023 & 1.000 & 0.063 \\
\hline 6 & Bangladesh & 0.330 & 0.537 & 0.024 & 0.500 & 0.493 \\
\hline 7 & Belgium & 1.000 & 0.305 & 0.029 & 1.000 & 0.083 \\
\hline 8 & Bolivia & 0.660 & 0.492 & 0.004 & 0.667 & 0.212 \\
\hline 9 & Bosnia and Herzegovina & 0.660 & 0.420 & 0.002 & 0.667 & 0.103 \\
\hline 10 & Brazil & 0.950 & 0.477 & 0.187 & 0.833 & 0.159 \\
\hline 11 & Bulgaria & 1.000 & 0.378 & 0.007 & 0.833 & 0.204 \\
\hline 12 & Cambodia* & 0.600 & 0.522 & 0.002 & 0.333 & 0.300 \\
\hline 13 & Canada & 1.000 & 0.283 & 0.091 & 1.000 & 0.111 \\
\hline 14 & Chile & 0.660 & 0.375 & 0.021 & 1.000 & 0.363 \\
\hline 15 & China, $\mathrm{PR}^{*}$ & 1.000 & 0.508 & 0.826 & 0.167 & 0.296 \\
\hline 16 & Croatia & 1.000 & 0.392 & 0.006 & 0.833 & 0.145 \\
\hline 17 & Czech Republic & 1.000 & 0.282 & 0.019 & 1.000 & 0.112 \\
\hline 18 & Denmark & 1.000 & 0.267 & 0.016 & 1.000 & 0.099 \\
\hline 17 & Dominican Republic & 0.660 & 0.447 & 0.007 & 0.833 & 0.169 \\
\hline 20 & Ecuador & 0.330 & 0.498 & 0.009 & 0.667 & 0.347 \\
\hline 21 & Egypt & 0.000 & 0.452 & 0.054 & 0.333 & 0.265 \\
\hline 22 & El Salvador & 0.330 & 0.478 & 0.003 & 0.667 & 0.174 \\
\hline 23 & Estonia & 1.000 & 0.303 & 0.002 & 1.000 & 0.169 \\
\hline 24 & Finland & 1.000 & 0.272 & 0.014 & 1.000 & 0.100 \\
\hline 25 & France & 1.000 & 0.333 & 0.156 & 1.000 & 0.165 \\
\hline 26 & Germany & 1.000 & 0.300 & 0.217 & 1.000 & 0.115 \\
\hline 27 & Greece & 0.970 & 0.452 & 0.022 & 0.833 & 0.209 \\
\hline 28 & Guatemala & 0.330 & 0.528 & 0.006 & 0.500 & 0.113 \\
\hline
\end{tabular}


Broto Wardoyo

\begin{tabular}{|c|c|c|c|c|c|c|}
\hline No & case & civ_con & in_threat & econ_cd & civ_lib & ac_res \\
\hline 29 & Honduras & 0.420 & 0.548 & 0.002 & 0.500 & 0.159 \\
\hline 30 & Hungary & 1.000 & 0.333 & 0.014 & 1.000 & 0.084 \\
\hline $\mathbf{3 1}$ & Iceland & 1.000 & 0.255 & 0.001 & 1.000 & 0.012 \\
\hline 32 & India & 1.000 & 0.597 & 0.359 & 0.667 & 0.405 \\
\hline 33 & Indonesia & 0.780 & 0.452 & 0.134 & 0.667 & 0.146 \\
\hline 34 & Israel & 1.000 & 0.658 & 0.015 & 0.833 & 0.596 \\
\hline 35 & Italy & 1.000 & 0.397 & 0.138 & 0.833 & 0.136 \\
\hline 36 & Japan* & 1.000 & 0.225 & 0.289 & 0.833 & 0.102 \\
\hline 37 & Korea North* & 0.000 & 0.592 & 0.001 & 0.000 & 1.000 \\
\hline 38 & Korea South & 1.000 & 0.325 & 0.101 & 0.833 & 0.529 \\
\hline 39 & Laos* & 0.600 & 0.393 & 0.002 & 0.167 & 0.043 \\
\hline 40 & Latvia & 1.000 & 0.375 & 0.002 & 1.000 & 0.102 \\
\hline 41 & Liberia & 0.730 & 0.480 & 0.000 & 0.500 & 0.081 \\
\hline 42 & Lithuania & 1.000 & 0.345 & 0.004 & 1.000 & 0.085 \\
\hline 43 & Macedonia & 0.660 & 0.473 & 0.002 & 0.667 & 0.170 \\
\hline 44 & Malaysia* & 0.800 & 0.325 & 0.039 & 0.500 & 0.224 \\
\hline 45 & Mali & 0.850 & 0.522 & 0.002 & 0.667 & 0.271 \\
\hline 46 & Mexico & 0.590 & 0.532 & 0.116 & 0.667 & 0.084 \\
\hline 47 & Montenegro & 0.660 & 0.450 & 0.001 & 0.833 & 0.159 \\
\hline 48 & Myanmar & 0.000 & 0.533 & 0.003 & 0.000 & 0.520 \\
\hline 49 & Namibia & 0.890 & 0.408 & 0.001 & 0.833 & 0.439 \\
\hline 50 & Nepal & 0.860 & 0.520 & 0.004 & 0.500 & 0.348 \\
\hline 51 & Netherlands & 1.000 & 0.318 & 0.050 & 1.000 & 0.111 \\
\hline 52 & New Zealand & 1.000 & 0.242 & 0.009 & 1.000 & 0.131 \\
\hline 53 & Nicaragua & 0.540 & 0.438 & 0.002 & 0.500 & 0.090 \\
\hline 54 & Norway & 1.000 & 0.275 & 0.019 & 1.000 & 0.138 \\
\hline 55 & Pakistan & 0.320 & 0.742 & 0.048 & 0.333 & 0.726 \\
\hline 56 & Paraguay & 0.660 & 0.475 & 0.003 & 0.667 & 0.214 \\
\hline 57 & Peru & 0.600 & 0.510 & 0.019 & 0.667 & 0.251 \\
\hline 58 & Philippines & 0.400 & 0.648 & 0.034 & 0.667 & 0.255 \\
\hline
\end{tabular}


Establishing Civilian Control over the Armed Forces

\begin{tabular}{|c|c|c|c|c|c|c|}
\hline No & case & civ_con & in_threat & econ_cd & civ_lib & ac_res \\
\hline 59 & Poland & 1.000 & 0.293 & 0.053 & 1.000 & 0.161 \\
\hline 60 & Portugal & 1.000 & 0.310 & 0.019 & 1.000 & 0.153 \\
\hline 61 & Romania & 1.000 & 0.378 & 0.022 & 0.833 & 0.131 \\
\hline 62 & Russia & 0.790 & 0.615 & 0.196 & 0.333 & 0.405 \\
\hline 63 & Rwanda & 0.000 & 0.475 & 0.001 & 0.333 & 0.202 \\
\hline 64 & Senegal & 0.840 & 0.468 & 0.002 & 0.667 & 0.224 \\
\hline 65 & Serbia & 0.660 & 0.453 & 0.006 & 0.833 & 0.203 \\
\hline 66 & Singapore* & 1.000 & 0.342 & 0.024 & 0.500 & 0.920 \\
\hline 67 & Slovakia & 1.000 & 0.307 & 0.009 & 1.000 & 0.122 \\
\hline 68 & Slovenia & 1.000 & 0.282 & 0.004 & 1.000 & 0.140 \\
\hline 69 & South Africa & 0.920 & 0.525 & 0.040 & 0.833 & 0.142 \\
\hline 70 & Spain & 1.000 & 0.388 & 0.101 & 1.000 & 0.121 \\
\hline 71 & Sri Lanka^^ & 0.750 & 0.665 & 0.011 & 0.500 & 0.541 \\
\hline 72 & Sweden & 1.000 & 0.250 & 0.026 & 1.000 & 0.097 \\
\hline 73 & Syria & 0.000 & 0.467 & 0.004 & 0.167 & 0.545 \\
\hline 74 & Taiwan & 1.000 & 0.322 & 0.030 & 0.833 & 0.406 \\
\hline 75 & Thailand & 0.000 & 0.598 & 0.059 & 0.500 & 0.288 \\
\hline 76 & Timor Leste & 0.660 & 0.417 & 0.000 & 0.500 & 0.139 \\
\hline 77 & Turkey & 0.620 & 0.547 & 0.078 & 0.667 & 0.267 \\
\hline 78 & UK & 1.000 & 0.338 & 0.150 & 1.000 & 0.213 \\
\hline 79 & Uruguay & 1.000 & 0.342 & 0.004 & 1.000 & 0.257 \\
\hline 80 & USA & 1.000 & 0.360 & 1.000 & 1.000 & 0.471 \\
\hline 81 & Vietnam* & 0.800 & 0.397 & 0.026 & 0.333 & 0.307 \\
\hline
\end{tabular}

